\title{
Brennan, James R. Taifa : Making Nation and Race in Urban Tanzania
}

Ohio University Press, 2012

\section{Marie-Aude Fouéré}

\section{OpenEdition}

\section{Journals}

Édition électronique

URL : https://journals.openedition.org/eastafrica/366

DOI : 10.4000/eastafrica.366

ISSN : 2790-1076

Éditeur

IFRA - Institut Français de Recherche en Afrique

Édition imprimée

Date de publication : 1 septembre 2014

Pagination : 197

ISSN : 2071-7245

Référence électronique

Marie-Aude Fouéré, «Brennan, James R. Taifa : Making Nation and Race in Urban Tanzania », Les Cahiers d'Afrique de l'Est / The East African Review [En ligne], 49 | 2014, mis en ligne le 07 mai 2019, consulté le 09 décembre 2021. URL : http://journals.openedition.org/eastafrica/366 ; DOI : https://doi.org/ 10.4000/eastafrica.366

Ce document a été généré automatiquement le 9 décembre 2021.

Les Cahiers d'Afrique de l'Est / The East African Review 


\section{Brennan, James R. Taifa : Making Nation and Race in Urban Tanzania}

Ohio University Press, 2012

Marie-Aude Fouéré

1 Cet ouvrage de James Brennan, maître de conférences à l'université d'Illinois après un parcours d'enseignant à la School of Oriental and African Studies (SOAS), retrace l'émergence des idées de race et de nation (toutes deux désignées par le même swahili de taifa) à Dar es Salaam dans les années 1940-1960. Rassemb lant en partie des articles universitaires déjà publiés à partir sa thèse, l'auteur montre comment la race, utilisée pour penser les différences entre Indiens et Arabes, est non seulement un produit de l'histoire sociale, économique et légale, mais aussi urbaine, de la capitale du Tanganyika, mais ont aussi été des outils pour penser et agir, divisant les populations spatialement, culturellement et politiquement. L'ouvrage prend place dans une historiographie américaine sur le Tanganyika / la Tanzanie qui interroge les causes et les effets de la race (voir Jonathon Glassman sur Zanzibar) en insistant sur les racines locales d'une pensée raciale, plutôt que de l'appréhender uniquement comme réappropriation de catégories coloniales importées.

\section{INDEX}

Index géographique : Tanzania | Tanzanie 